Omni-Akuatika, 14 (3): 60-65, 2018
ISSN: 1858-3873 print / 2476-9347 online
Research Article
journal homepage: http://ojs.omniakuatika.net

\title{
Substitution of Fish Meal with Chicken Feather Silage Meal on Diet Can Improve Growth Performance of Striped Catfish (Pangasius hypopthalmus)
}

\author{
Diana Rachmawati ${ }^{1, *}$, Istiyanto Samidjan ${ }^{1}$, Dicky Harwanto ${ }^{1}$, Hadi Pranggono ${ }^{2}$ \\ ${ }^{1}$ Aquaculture Department, Faculty of Fisheries and Marine Sciences, Diponegoro University, Semarang, \\ 50275, Indonesia \\ ${ }^{2}$ Aquaculture Study Program, Faculty of Fisheries, Pekalongan University, Indonesia \\ ${ }^{*}$ Corresponding author: dianarachmawati1964@gmail.com
}

Received 29 March 2018; Accepted 25 November 2018; Available online 30 November 2018

\begin{abstract}
This study aimed to examine the effect of substitution of fish meal with silage meal of chicken feathers on diet to protein digestibility, growth and survival rate of striped catfish (Pangasius hypopthalmus). The test fish used is catfish with an average weight of $2.31 \pm 0.04 \mathrm{grams} / \mathrm{fish}$. The experimental method was used based on completely randomized design, 5 treatments and 4 repetitions. The treatments in this study were substitution of fish meal with different dose of chicken feather silage, namely A $(0 \%), \mathrm{B}(25 \%), \mathrm{C}$ $(50 \%), D(75 \%)$ and E (100\%). Parameters observed included relative growth rate (RGR), feed conversion ratio (FCR), protein efficiency ratio (PER), apparent digestibility coefficient of protein $\left(A D C_{P}\right)$, and survival rate (SR) of catfish. The results showed that substitution of fish meal with chicken silage meal could improve protein digestibility and growth of $P$. hypopthalmus. Substitution silage with rate of $25 \%$ substitution chicken feather is the best dose for protein digestibility and growth of $P$. hypopthalmus. Water quality during the study was still within a reasonable range for catfish culture.
\end{abstract}

Keywords: catfish, chicken feathers, diet, growth, silage

\section{Introduction}

Striped catfish (Pangasius hypopthalmus) is one of the fish commodities that have high economic value both as a consumption fish and ornamental fish. Intensive cultivation of the catfish is very dependent on the existence of artificial diet quality. On the other hand, the quality of diet is determined by the protein content. Protein is an important nutrient in diet both the quality and quantity of protein is very important for fish growth from seed size to consumption (Suloma et al., 2014).

Fish meal in artificial diet to date is used as a source of animal protein. However, the use of fish meal in the diet has the main problems of rising costs, uncertain availability, counterfeiting and quality variations. With the increasing demand for unstable fish meal stocks and high fish diet prices, and also with the expansion of cultivation activities, it is necessary to look for alternative sources of protein (FAO, 2013).
Chicken feather meal is an alternative protein source that can be used to replace fish meal in the diet. According to Sarmwatanakul and Bamrongtum (2000), chicken meal comprises a complex protein (keratin) that can be broken down through hydrolysis, making it easier to digest. Keratinase has excellent ability to decrease keratin through the reshuffling of chemical cell wall structure, disconnection of hydrogen fish and keratin disulfide bonds (Suloma et al., 2014). The silage process in chicken feather meal can make the diet digested more efficiently by the fish. This is because of the role of microbes in the silage process as mentioned by Suloma et al. (2014) that microbes derived from one spore cell will grow into an individual and produce keratinase enzymes that play a role in breaking the complex peptide (keratin) bond into simple peptide bonds. Chicken feather meal contains an easily digestible protein $(75-87 \%)$ and is rich in essential amino acids such as cystine, threonine, 
and arginine and its amino acids are balanced with fish meal and soybean meal (Sarmwatanakul and Bamrongtum, 2000).

Substitution studies of chicken feather meal in diet for several species of fish have been reported, among others Chinook Salmon Onchorhynchus tshawytscha (Fowler, 1990), Rainbow Trout Oncorhynchus mykiss (Pfeffer et al., 1994), Hybrid Clarias Catfish (Arunlertaree and Rakyuttithamkul, 2006 ), Oreochromis niloticus (Arunlertaree and Moolthongnoi, 2008; Kumari and Sundarabarathy, 2011), Humback groupers Cromileptes altivelis (Shapawi et al., 2007), Fish African catfish Clarias gariepinus (Chor et al., 2013), and Oreochromis niloticus (Suloma et al., 2014). However, a substitution study of fish meal with silage meal of chicken feather in Tilapia (Oreochromis niloticus) diet has not been reported to date. Thus, it is necessary to research on the use of chicken feather flour as a substitute for fish meal in the diet of catfish.

\section{Materials and Methods}

In this study, fish larvae of $P$. hypopthalmus were obtained from catfish farmer in Subang district, West Java, Indonesia. The weight of larvae was about $2.31 \pm 0.04 \mathrm{~g}$. The test fish used were selected based on size, weight, completeness of body organs and physical health (Rachmawati et al., 2017).

The test diet used in this study was a pellet-shaped artificial diet, with a protein content of $30 \%$ (isoprotein) and energy of $2.72 \mathrm{kcal} / \mathrm{g}$ diet (iso-energy). The treatments in this research were substitution of fish meal with silage of chicken feather meal in diet with different doses i.e. A $(0 \%$ chicken feather silage), B $(25 \%$ chicken feather silage), C (50\% chicken feather silage), D $75 \%$ chicken feather silage), and $E$ (100\% chicken feather silage). The determination of substitution dosage of fish meal with silage meal in diet was from modifying the results of Arunlertaree and Moolthongnoi (2008).

Table 1. Formulation of test diet used in the study

\begin{tabular}{|c|c|c|c|c|c|}
\hline \multirow{2}{*}{ Food Composers Materials $(\mathrm{g} / 100 \mathrm{~g})$} & \multicolumn{5}{|c|}{ Composition (\%) } \\
\hline & $A(0)$ & $B(25)$ & $\mathrm{C}(50)$ & $\mathrm{D}(75)$ & $E(100)$ \\
\hline Fish meal & 28.00 & 18.00 & 12.00 & 6.00 & 0.00 \\
\hline Chicken Feather Silage Meal & 0.00 & 7.50 & 11.50 & 16.00 & 19.50 \\
\hline Soybean Meal & 22.00 & 20.00 & 19.00 & 19.15 & 19.15 \\
\hline Cornstarch & 15.00 & 16.50 & 16.50 & 17.00 & 18.00 \\
\hline Bran Meal & 15.45 & 17.50 & 19.50 & 19.50 & 20.00 \\
\hline Wheat meal & 13.00 & 13.50 & 14.30 & 15.00 & 16.00 \\
\hline Fish oil & 1.00 & 1.00 & 1.00 & 1.00 & 1.00 \\
\hline Corn oil & 1.00 & 1.00 & 1.00 & 1.00 & 1.00 \\
\hline Mineral-Vitamin mix & 3.00 & 3.00 & $3, .00$ & 3.00 & 3.00 \\
\hline $\mathrm{C}_{\mathrm{r}} 2 \mathrm{O}_{3}$ & 0.5 & 0.5 & 0.5 & 0.5 & 0.5 \\
\hline $\mathrm{CMC}$ & 2.00 & 2.00 & 2.00 & 2.00 & 2.00 \\
\hline Total $(\mathrm{g})$ & 100.00 & 100.00 & 100.00 & 100.00 & 100.00 \\
\hline \multicolumn{6}{|l|}{ Result of Proximate Analysis } \\
\hline Protein $(\%)^{\star}$ & 30.35 & 30.23 & 30.07 & 30.65 & 30.44 \\
\hline Fat $(\%)^{*}$ & 7.8 & 6.75 & 6.25 & 5.75 & 5.27 \\
\hline $\begin{array}{l}\text { BETN }(\%)^{*} \\
\text { Energy }(\mathrm{kkal} / \mathrm{g})^{\mathrm{a}}\end{array}$ & $\begin{array}{c}41.74 \\
272.74\end{array}$ & $\begin{array}{c}44.82 \\
272.56\end{array}$ & $\begin{array}{c}46.62 \\
272.44\end{array}$ & $\begin{array}{c}48.3 \\
273.85\end{array}$ & $\begin{array}{c}50.29 \\
274.95\end{array}$ \\
\hline Ratio of E/P (kkal/g P) ${ }^{b}$ & 8.99 & 9.02 & 9.06 & 8.94 & 9.03 \\
\hline
\end{tabular}

Note:

* Results of proximate analysis of Livestock Diet Laboratory, Faculty of Animal Husbandry and Agriculture, Diponegoro University (2017).

a. Calculated based on Digestible Energy according to Wilson (1982) for $1 \mathrm{~g}$ of protein is $3.5 \mathrm{kcal} / \mathrm{g}, 1 \mathrm{~g}$ of fat is 8.1 $\mathrm{kcal} / \mathrm{g}$, and $1 \mathrm{~g}$ of carbohydrate is $2.5 \mathrm{kcal} / \mathrm{g}$.

b. According to De Silva (1987), the E / P value for optimal growth of fish ranges from $8-12 \mathrm{kcal} / \mathrm{g}$. 
The ingredients used to make the diet in this research include fish meal, chicken feather silage, soybean meal, corn meal, bran meal, wheat meal, fish oil, corn oil, minerals and vitamin mix, $\mathrm{CMC}$ and $\mathrm{Cr}_{2} \mathrm{O}_{3} 0.5 \%$ (NRC, 1993). Preparation of test diet conducted in this research plan, among others, to test proximate diet ingredients, formulate and make the diet. The process of making the diet begins with the process of chicken feather silage by using the addition of strong HCL acid (Puastuti, 2007). Furthermore, the dieting process is carried out by weighing the necessary ingredients (Table 1), then mixing all the ingredients starting with the smallest to the greatest amount. After that the dough diet is printed in pellet form and inserted into the oven to dry (NRC, 1993). Proximate test results can be seen in Table 1 .

Container used in this research was a 60 $\mathrm{cm} \times 60 \mathrm{~cm} \times 40 \mathrm{~cm}$ aquarium. Aerator to recirculate the water was placed in every container. The frequency of dieting was 2 times a day where fish was fed little by little until the fish was full (ad satiation). Water quality parameters including temperature, dissolved oxygen (DO), $\mathrm{pH}$ and ammonia were measured. Temperature measurements were performed daily in the morning and afternoon. The measurement of DO and $\mathrm{pH}$ was done once a week. Meanwhile, ammonia was measured at the beginning, middle and end of the study. Sampling was done once a week to measure the weight of test fish.

Parameters observed included relative growth rate (RGR), protein efficiency ratio (PER), diet conversion ratio (FCR) (Tacon, 1987), apparent digestibility coefficient of protein $\left(A D C_{P}\right)$ (Fenucci, 1981), and survival rate (SR) (NRC, 1993). Analysis of $\mathrm{Cr}_{2} \mathrm{O}_{3}$ using modified calorimetric method (Fenucci, 1981). The $\mathrm{pH}$, $\mathrm{DO}$, temperature and Ammoniac were using water quality checker.

The parameters were calculated by the following formula:

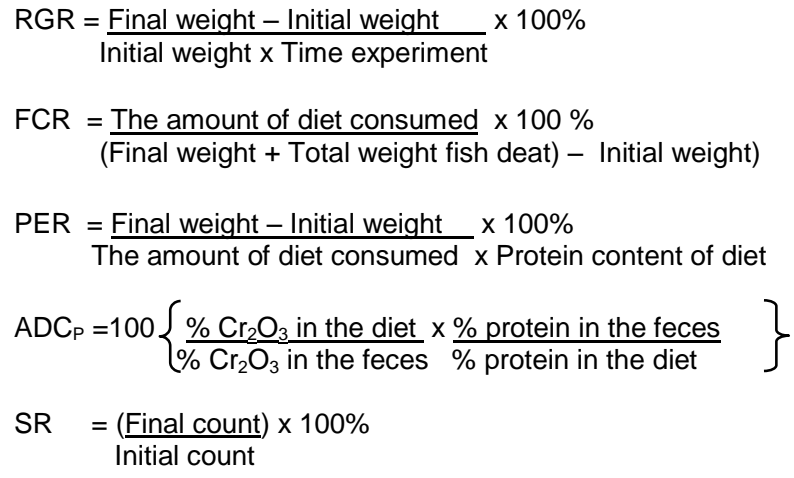

The data were tested by ANOVA. For the very significant $(P<0.01)$ or significant $(P<0.05)$ results, the Duncan test was performed (Steel et al., 1996). Water quality parameters were analyzed descriptively.

\section{Results and Discussion}

The results of observation of RGR, PER, $\mathrm{FCR}, \mathrm{ADC}_{\mathrm{P}}$ and $\mathrm{SR}$ of $P$. hypopthalmus can be seen in Table 2.

Table 2. The values of RGR, PER, FCR, ADC $P$ and SR of catfish (P. hypopthalmus)

\begin{tabular}{lccccc}
\hline \multirow{2}{*}{ Data } & \multicolumn{5}{c}{ Treatment (percentage of chicken feather silage composition) } \\
\cline { 2 - 6 } & $\mathrm{A}(0 \%)$ & $\mathrm{B}(25 \%)$ & $\mathrm{C}(50 \%)$ & $\mathrm{D}(75 \%)$ & $\mathrm{E}(100 \%)$ \\
\hline RGR (\%/day) & $2.40 \pm 0.23^{\mathrm{c}}$ & $5.21 \pm 0.63^{\mathrm{a}}$ & $3.86 \pm 0.53^{\mathrm{b}}$ & $3.42 \pm 0.45^{\mathrm{b}}$ & $2.13 \pm 0.14^{\mathrm{c}}$ \\
FCR & $2.53 \pm 0.23^{\mathrm{c}}$ & $1.53 \pm 0.21^{\mathrm{a}}$ & $1.72 \pm 0.42^{\mathrm{b}}$ & $2.12 \pm 0.32^{\mathrm{c}}$ & $2.35 \pm 0.17^{\mathrm{c}}$ \\
PER & $1.25 \pm 0.64^{\mathrm{d}}$ & $2.59 \pm 0.34^{\mathrm{a}}$ & $2.06 \pm 0.31^{\mathrm{b}}$ & $1.82 \pm 0.61^{\mathrm{c}}$ & $1.23 \pm 0.23^{\mathrm{d}}$ \\
ADC $_{P}(\%)$ & $50.15 \pm 0.42^{\mathrm{d}}$ & $75.57 \pm 0.36^{\mathrm{a}}$ & $70.21 \pm 0.51^{\mathrm{b}}$ & $63.52 \pm 0.43^{\mathrm{c}}$ & $53.13 \pm 0.19^{\mathrm{d}}$ \\
SR (\%) & $98.60 \pm 0.63^{\mathrm{a}}$ & $99.44 \pm 0.54^{\mathrm{a}}$ & $96.78 \pm 0.53^{\mathrm{a}}$ & $98.56 \pm 0.54^{\mathrm{a}}$ & $97.98 \pm 0.51^{\mathrm{a}}$ \\
\hline
\end{tabular}

Note: The Values with the same superscripts in the same row show that there was no significant difference

Substitution of fish meal with chicken feather silage on the diet was highly significant (P <0.01) on RGR of $P$. hypopthalmus. The RGR of $P$. hypopthalmus in treatment B $(5.21 \%$ / day) was the highest among other treatments. The results are similar to those of Somsueb and Boonyaratpalin (2001), Arunlertaree and Rakyuttithamkul (2006) and Arunlertaree and
Moolthongnoi (2008). The high value of RGR of catfish fed $B$ is presumed to be the right diet for catfish in utilizing the essential amino acids contained in the diet so that the diet has an $A D C_{P}$, the FCR and the highest PER $(75.59 \%$, 1.53 and 2.59, respectively) that support growth. According to Sarmwatanakul and Bamrongtum (2000), chicken meal contains many essential 
amino acids such as cysteine, threonine, arginine and pepsin that are relatively high in protein digestibility of $75-87 \%$. Fish with treatment $E$ has the lowest relative growth rate. It is suspected that the smell of the diet affects the catfish so that appetite decreases. This opinion is supported by Somsueb and Boonyaratpalin (2001) which states that diet with $100 \%$ silage meal chicken feathers will appear smells that affect the palatability of fish.

The FCR is a calculation of how efficient fish are able to convert diet into fish meat (in $1 \mathrm{~kg}$ of meat) and the conversion as a reference or as a benchmark to the extent of the efficiency of fish enlargement efforts (Tacon, 1987). The amount of FCR value is a description of the level of diet efficiency given to the fish. The smaller the value the more efficiently the diet will be given (Steffens, 1994). Substitution of fish meal with chicken feather silage in diet had a very significant effect $(P<0.01)$ to $F C R$ of $P$. hypopthalmus. The value of fish FCR with treatment $B$ was the lowest among other treatments (Table 2). The results of this study indicate that the value of FCR of $P$. hypopthalmus will increase with the increasing number of silage meal of chicken feathers in the diet. This is similar to that of Hasan et al. (1997) who reported that FCR of Labeo rohita increased with increasing percentage of meal in fish diet. The lower FCR value (Treatment B) shows that the diet is better in quality, supported by $A D C_{P}$, PER and the highest RGR of $75.59 \%, 1.53$ and $5.21 \%$ / day, respectively. So it can be concluded that the diet on treatment $B$ can be eaten, digested, absorbed and utilized properly for the growth of $P$. hypopthalmus.

According to Tacon (1987), PER is used to determine the quality of proteins in diet. Quality of protein one of them is influenced by the level of protein digestibility. Protein is easily digested indicates that the amount of amino acids absorbed by the body is higher, thereby impacting on growth. Substitution of fish meal with chicken feather silage into diet had a significant effect $(P<0.01)$ to protein efficiency value of $P$. hypopthalmus ratio. The results showed that the highest PER value in $P$. hypopthalmus treatment B (2.59) and the lowest in treatment $E$ (1.23). The high value of PER of $P$. hypopthalmus Treatment $B$ because the diet has the highest $A D C_{p}(75.57 \%)$. This causes the amount of amino acids absorbed by the fish body higher so that it can be utilized properly for the formation of $P$. hypopthalmus body protein.

The value of $\mathrm{ADC}_{\mathrm{P}} P$. hypopthalmus Treatment $B, C$ and $D$ were higher when compared with treatment of $A$. The $P$ hypopthalmus treatment $B$ had the highest $A D C_{P}$ value of $75.57 \%$ and the higher percentage silage of chicken feathers the lower the $A D C_{P}$ of $P$. hypopthalmus. The high value of apparent digestibility coefficient of protein $P$. hypopthalmus Treatment $B$ showed that the diet was suitable to be digested by $P$. hypopthalmus resulting in the highest RGR, FCR and PER $(5.21 \%$ / day, 1.53 and 2.59, respectively). The results of this study are similar to those performed by Arunlertaree and Rakyuttithamkul (2006), indicating that the highest protein digestibility of catfish hybrid fish (Clarias macrocephalus x Clarias gariepinus) was fed $25 \%$ silage diet meal. Arunlertaree and Moolthongnoi (2008) stated that 25\% chicken silage meal on diet showed the highest protein digestibility of Oreochromis niloticus.

Substitution of fish meal with chicken feather silage on diet was not significant $(P>$ 0.05 ) on the SR of $P$. hypopthalmus. Similar results were reported by Pfeffer et al. (1994), Arunlertaree and Rakyuttithamkul (2006), Shapawi et al. (2007), Arunlertaree and Moolthongnoi (2008), Kumari and Sundarabarathy (2011), Chor et al. (2013) and Suloma et al. (2014). Water quality during the study is still in proper condition for catfish culture. Water quality parameters during the cultivation of $P$. hypopthalmus can be seen in Table 3 . 
Tabel 3. Parameters of water quality for Catfish ( $P$. hypopthalmus) cultivation

Water Quality

\begin{tabular}{ccccc} 
Treatment & \multicolumn{3}{c}{$\mathrm{DO}(\mathrm{mg} / \mathrm{l})$} & $\mathrm{NH}_{3}(\mathrm{mg} / \mathrm{l})$ \\
\cline { 2 - 5 } & Temperature $\left({ }^{0} \mathrm{C}\right)$ & $\mathrm{pH}$ & $4.23-4.85$ & $0.0052-0.0052$ \\
$\mathrm{~A}$ & $27.3-31.5$ & $6.78-8.32$ & $6.31-4.90$ & $0.0052-0.0052$ \\
$\mathrm{~B}$ & $27.5-31.0$ & $6.85-8.03$ & $4.05-4.65$ & $0.0052-0.0052$ \\
$\mathrm{D}$ & $27.5-31.5$ & $6.85-8.02$ & 4.25 & \\
Feasibility & $27.4-31.8$ & $6.85-8.03$ & $4.26-4.63$ & $0.0052-0.0052$ \\
\hline Note : ${ }^{*}$ Boyd (1992) & $14-38^{*}$ & $6.50-8.5^{*}$ & $>2^{*}$ & $<0.1^{*}$
\end{tabular}

\section{Conclusion}

The results showed that substitution of fish meal with chicken silage meal could improve protein digestibility and growth of $P$. hypopthalmus. Substitution silage with rate of $25 \%$ substitution chicken feather is the best dose for protein digestibility and growth of $P$. hypopthalmus.

\section{References}

Arunlertaree, C. and E. K. Rakyuttithamkul. 2006. Utilization of fermented feather meal as a replacement of fish in the diet of hybrid clarias catfish. Kasetsart Journal (Nat. Sci.). 40: 436-448.

Arunlertaree, C., and Moolthongnoi, C. 2008. The Use of Fermented Feather Meal for Replacement Fish Meal in the Diet (Oreochromis niloticus). Environment and Natural Resources Journal. 1(6):13-24.

Boyd, C.E. 1992. Shrimp pond bottom soil and sediment management. In: J. Wyban (Editor), Proceedings of the Special Session on Shrimp Farming. World Aquaculture Society, Baton Rouge, Louisiana, pp. 166-181.

Chor, W. K., L. S. Lim and R. Shapawi. 2013. Evaluation of feather meal as a dietary protein sources for African catfish fry, Clarias gariepinus. Journal of Fisheries and Aquatic Science. 8(6): 697-705.

Dasuki, A., Auta J., Oniye S. J. 2013. Effect of stocking density on production of Clarias gariepinus (Tuegels) in floating bamboo cafes at Kubanni Reservoir, Zaria, Nigeria. Journal of Pure and Applied Sciences. 6 (1) : $112-117$.

De Silva, SS. 1987. Finfish Nutrional Research in Asia. Proceeding of The Second Asian Fish Nutrion Network Meeting. Heinemann, Singapore. $128 \mathrm{p}$.

FAO. 2013. FAO yearbook, fishery and aquaculture statistics. Aquaculture production, Rome, p 118.

Fenucci, J.L. 1981. Studies on the nutrition of marine shrimp of the Penaeus. Ph.D. Thesis, Faculty of Department of Biology, University of Houston, Houston, Texas, USA.

Fowler, L.G. 1990. Feather meal as a dietary protein sources during parr smolt transformation in fall chinook salmon. Aquaculture. 89: 301-314.

Hasan M.R., M.S. Haq, P.M. Das., G. Mowlah. 1997. Evaluation of poultry-feather meal as a dietary protein source for Indian major carp, Labeo rohita fry. Aquaculture. 151: 47-54.

Hepher, B. 1988. Nutrition on Pond Fisheries. Cambridge University Press. Cambridge USA. p. 388.

Kumari, M. M. T., T.V. Sundarabarathy. 2011. Use of fermented feather meal in the artificial diet of gift tilapia (Oreochromis niloticus) fry. Annual Research Session 2011. Rajarata University of Sri Lanka. 14. 
National Research Council (NRC). 1993. Nutrition Reqruitment of Warm Water National Research Council of Canada. Canada.

Pfeffer, E., D. Wiesmann and B. Henrichfreise. 1994. Hydrolyzed feather meal as diet component in diets for rainbow trout (Oncorhynchus mykiss) and effect of protein/ energy ratio on the efficiency of utilization of digestible energy and protein. Arch. Anim. Nutr. 46: 111-119.

Puastuti, W. 2007. Teknologi pemrosesan bulu ayam dan pemanfaatannya sebagai sumber protein pakan ruminansia. Wartazoa. 17(2): 53-60.

Rachmawati, D., Istiyanto, S., Maizirwan, M. 2017. Effect of phytase on growth performance, diet utilization efficiency and nutrient digestibility in Fingerlings of Chanos chanos (Forsskal 1775). Philippine Journal of Science. 146 (3):237245.

Sarmwatanakul A. and B. Bamrongtum. 2000. Aquarium Fish Nutrition. Extension paper No. 1/2000. Ornament Fish Research and Public Aquarium. Bangkok.

Shapawi, R., W.K. Ng and S. Mustafa. 2007. Replacement of fishmeal with poultry byproduct meal in diets formulated for the polka-dot grouper, Cromileptes altivelis. Aquaculture. 273: 118-126.

Somsueb P. and M. Boonyaratpalin. 2001. Use of feather meal in Hybrid Clarias Catfish diet (Clarias macrocephalus X Clarias gariepius). Technical Paper No.5/2001. Diet Quality Control and Development Division, Department of Fisheries. Bangkok.

Steel, R.G.D. Torrie, J.H., and Dickey, D.A. 1996. Principles and procedures of statistics, $3^{\text {rd }}$ ed. New York: McGraw Hill International Book Company, Inc.

Steffens, W. 1994. Replacing fish meal with poultry by product meal in diet for rainbow trout, Oncorhynchus mykiss. Aquaculture. 124:27-34.

Suloma, A., O. M. El. Husseiny, M. I. Hassane, R. S. Mabroke., E. R. El-Haroun. 2014. Complementary responses between hydrolyzed feather meal, fish meal and soybean meal without amino acid supplementation in Nile Tilapia Oreochromis niloticus diets. Aquacult Int. 6(10): 201-218.

Tacon, A.G. 1987. The Nutrition and Dieting of Farmed Fish and Shrimp-A Traning Mannual. FAO of the United Nations, Brazil, pp. 106-109.

Wilson, R.P. 1994. Utilization of dietary carbohydrate by Fish. Aquaculture Journal. 124:67-80 p. 